I University of Oslo, Department of Culture Studies and

Oriental Languages, Oslo, Norway

a.l.ahlers@ikos.uio.no

https://orcid.org/0000-0003-1072-8823

I I University of Bonn, Bonn, Germany

rstichweh@yahoo.de

https://orcid.org/0000-0002-4028-0970

Anna L. Ahlers'

Rudolf Stichweh"

\title{
THE BIPOLARITY OF DEMOCRACY AND AUTHORITARIANISM: VALUE PATTERNS, INCLUSION ROLES AND FORMS OF INTERNAL DIFFERENTIATION OF POLITICAL SYSTEMS
}

\section{INTRODUCTION}

A Recession of Democracies?

There are conflicting signals concerning the global political landscape in the twenty-first century. When looking at the vehement political protests seen worldwide since 2000 and especially in the early 2010 s, most importantly the 'colour revolutions' in the successor states of the former Soviet Union, the Arab Spring revolts, mass rallies in Brazil and Chile, clashes in Turkey, umbrella protests in Hong Kong - not a few observers came to diagnose a 'fourth wave of

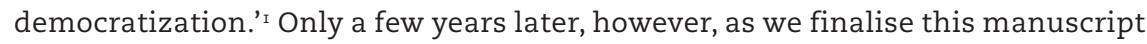
in October 20I9, the latest rounds of political protest are found not to have resulted in any notable increase in democratic political regimes worldwide. On the contrary, the international media, as well as the social science research community, are diagnosing a new 'wave of authoritarianism.' This seems to be symbolized by the return to a highly personalized and uncompromising type of autocracy in countries such as Venezuela, Russia, Turkey and China, the recurrence and astonishing success of nationalist populist governments in Europe and lately the Americas, the authoritarian-leaning re-emergence of one-party dominance in Japan, and the full transformation back to authoritarianism after a relatively short democratic period of countries of the so-called 'third wave,' such as Egypt, Kenya, Thailand and the Philippines. Some major international political barometers have even come to note a 'recession of democracy.' 


\begin{abstract}
During the I970s and I980s, more than 30 countries shifted from authoritarian to democratic political systems. In recent years, the post-I97os wave of democratisation has slowed or been reversed. [...] We expect that political upheavals will affect other authoritarian regimes in future. These may not all be successful and not all will necessarily take the form of mass popular uprisings. The outlook for democratic transition is, however, uncertain. As in recent years, there are historical examples of major reversals of democratisation. [...] Democracy's proponents have become increasingly circumspect about the prospects of a further wave of democratisation (Economist Intelligence Unit, 20I4: I5-I6.). In addition, several bestselling books now talk about the "death of democracy." (Levitsky \& Ziblatt, 20I8; Runciman, 20I8).
\end{abstract}

\title{
Bipolarity: Trends in the Classification of Political Regimes?
}

Besides the ups and downs of democracies (and authoritarian regimes), another regime discontinuity can be observed. There are no longer any totalitarian regimes (North Korea may be the exception), and socialism and communism no longer really matter as genuine terms for political regimes, as the discussion about their applicability to the largest remaining example, the one-party rule of the Communist Party in China, strikingly illustrates. ${ }^{3}$ It is this discontinuity that gives a new prominence to the bipolar structure of democracy and authoritarianism on which the argument of this paper centres. Interestingly enough, regime differences alone no longer seem to constitute a life and death issue in international relations and have mostly been replaced by other cleavages and conflicts. Especially since the end of the Cold War and its strict ideological bifurcations from which cooperation or conflict followed quasi 'deductively,' binational and multinational cooperation across regime types have become more common in recent decades. In particular, issue-based international cooperation and global governance, most prominently in the field of nuclear non-proliferation and climate change mitigation, seem possible without much fuss about the regime labels of the systems involved. Classification becomes very relevant, however, when governments of liberal democratic countries seek reliability and predictability in cooperation, as well as legitimation for the latter from their publics. This recently became vividly apparent in Europe's 'refugee crisis,' when affected publics discussed whether it is appropriate to collaborate with - or even become dependent on - non-democratic 'despotic' regimes or 'failing states' in the Bosporus and North-Africa in trying to stem the influx of migrants to their countries.

At the same time, there seems to be a resurgence of scholarly interest in the description and analysis of political regimes. Beyond arguing for viable classificatory schemes and the most suitable forms of tracing transformation(s), intellectual discussions have centred especially on regime qualities - that is, the effects, or even efficiency, of certain modes of rule. Notwithstanding concerns about human rights records, the performance sheets of some of the re- 
silient modern autocracies - most notably China, Singapore and perhaps Saudi Arabia - have led some analysts to discern 'models' of authoritarian effectiveness. Diagnoses such as 'developmental autocracy' or 'authoritarian capitalism,'4 the 'Beijing Consensus,' (Ramo, 2004)5 or the successful 'segmented clientelism' of rentier states (Hertog, 20I I) reflect the observation that some goals may be (better) achieved by authoritarianism. Especially when it comes to issue-based analyses, the performance 'advantages' of different regime types, including some very specific structures and procedures of their political systems, are held against each other, as in the 'democratic environmentalism' versus 'authoritarian environmentalism' debate. ${ }^{6}$ This means that, following the collapse of the capitalism/socialism divide, there is a certain inescapability of the democracy/autocracy bifurcation - as long as no alternative distinction arises. Therefore, it is established as the most important distinction in observing structures of political decision making. And it is used by both academic observers and political actors themselves, acquiring a significant semantic complexity.

\section{Paradoxes of Regime Bipolarity Internal to and b eyond the Nation State}

Conventional studies in comparative political science map the diverse landscape of regimes found in today's global society. Their large and meticulous data sets are a treasure trove and, among other things, have helped to throw into question the almost teleological undertone or 'democracy bias' of some earlier political science research.7 But is this country-to-country comparison really the ultimate diagnostic instrument to understand macro-political developments? Do regime characteristics accumulated and identified at the nation state level help us understand all the traits of political evolution in world society $?^{8}$ By focusing on national-level regime features, some dynamics and structures may go unnoticed. It is obvious that the bipolarity of democratic vs. authoritarian structures and processes is not only relevant on the level of the national-territorial states. There may exist authoritarian enclaves in an otherwise democratic polity and islands of democracy in an authoritarian environment. This reflects a general feature of sociological differentiation theory. As soon as a system produces a hierarchy of levels of horizontally differentiated subsystems (national states and regional states and local government and village polities) there are no a priori theoretical reasons why relevant properties should only exist on one of these levels.

One has to study the similarities and discontinuities across levels and the intra-level oscillations between the two poles of the bipolar distinction democracy and autocracy. Interesting cases for study are the oft-lamented 'democracy deficit' in European Union politics at supra state level, ${ }^{9}$ or the brief dominion of the so-called Islamic State (ISIL) whose rule and public infrastructure and rule temporarily stretched across the territories of several different 
states (Birke, 20I5), the authoritarian enclaves identified by political scientists in the 'deep South' of the otherwise democratic United States and in Argentina and Mexico (Mickey, 20I5; Giraudy, 20I5), the outsourcing of decision making on core policies in many democracies to non-majoritarian institutions such as central banks or courts, ${ }^{\text {to }}$ the retreat of parliaments in exemplary Scandinavian democracies as they cede to decision making informed by technocratic committees of experts, ${ }^{\text {II }}$ the global Occupy movement and its claims to act (sometimes violently) on behalf of the majority of the world population, and the many localized or national protest movements in the OECD world (postBrexit, post-Trump) which act on the basis of the same claims and obviously see no means - and sometimes may have no interest - to push for their demands via formal democratic institutions (see Roberts, 20I 2), the recent admittance of women to participate in elections and run for office in Saudi Arabia's municipal elections (see Al Jazeera, 20I5), or finally the village-level democratic elections in present-day China (see Schubert \& Ahlers, 20I2), to name just a few paradoxes and discontinuities. All these examples point to the dynamics built into the distinction of democracy and authoritarianism, which seems to inform oscillations between these two poles of political spaces.

To the divergences across levels and the oscillations between democratic and autocratic tendencies internal to political units we have to add a third form of structural ambivalence built into political systems. It may be the case that political systems are always built from institutions some of which have an inherent democratic or authoritarian character and which then function as components in systems with different labels. There is the institution of the (directly elected) president in a democracy who has often been compared to a monarch (Washington, De Gaulle). There is the military which has mostly been based on authoritative decisions. A bureaucracy is another institution which is not easily democratised. On the other side of this distinction of democratic and autocratic institutions we locate collegial structures of decision making and the parliament as a deliberative institution.

\section{A Novel Analytical Approach to the Bipolarity of Democracy and Authoritarianism}

In this article we try to move from a purely descriptive understanding of democracies and autocracies to an analytical and genetical interpretation. Therefore, we argue for an approach to the bipolarity of political regimes that rests on a sociological theory of functional differentiation and political inclusion. There are three parts to our argument. First, we base our analysis on the hypothesis of a divergent stance towards societal values and value formation present in different political systems. And this divergent stance towards values is related to different relations between polities and the other function systems in society which clearly distinguish between democracies and autocracies. Second, we note that 
independent of the recurrent "waves of democratization and authoritarianism," there is an underlying theme and tendency in modern society: the relevance of individual inclusion into forms of collectively binding decision making. Put even more succinctly, we propose that there is an inclusion imperative that is increasingly observable in self-descriptions and institutional configurations of almost all political regimes. While democracy can be regarded as the ideal type of universal political inclusion, we argue that under conditions of modernity, global complexity and mutual comparison, even non-democratic political systems have come under increasing pressure to allow for the political inclusion of individuals. A major question for modern social theory is where exactly this strong imperative of individual inclusion in modern society comes from. Since these developments are not sufficiently visible when looking solely at the macro patchwork of country units on a global map, we conclude by, thirdly, suggesting an approach towards embedding and deepening both aforementioned observations. Based on an interpretation of political systems informed by sociological systems theory, we propose and test explorations of the ways in which the challenges of the inclusion imperative are dealt with at varying vertical levels of the polity as a function system ${ }^{12}$ and in its different horizontal subsystems. We argue that such an approach, by fully taking into account the internal differentiation of contemporary political systems, will provide more accurate understandings of the components of democracy and autocracy present in political systems than those achieved by an analysis that remains limited to the nation state level.

\section{VALUE PATTERNS OF DEMOCRATIC AND AUTHORITARIAN REGIMES}

Among the myriad attempts to categorize political regimes, the most common catalogues are based on a scale oriented to an ideal type, with the most 'desirable' regimes, the democracies, located at one end of the continuum, and the latecomers, failing, defective and yet-to-be transformed non-democracies at the other. Under these premises, only a 'negative' understanding of authoritarianism exists, defined by the properties that authoritarian regimes lack. Most typologies follow a strictly institutionalist approach and concentrate on aspects such as free and fair elections, freedom of speech, and rule of law, as observable at the national level. ${ }^{\mathrm{I} 3}$ Depending on the number of variables included, these catalogues often also list numerous subcategories of regime types 'with attributes' (e.g. 'competitive authoritarianism,' 'electoral authoritarianism,' 'defective democracies,' 'illiberal democracy,' or simply 'hybrid regimes') (Levitsky \& Way, 2010; Schedler, 2006; Merkel, 2004; Zakaria, I997; Diamond, 2002). While the analysis of authoritarian regimes is now in vogue again and the resilience of many of these regimes is increasingly acknowledged, most of these indices nonetheless seem to be driven by the teleological expectation that, in the long run, all political entities will eventually converge on one of the forms of democracy. 
We agree with the observation that in today's world society we can basically distinguish between democratic and non-democratic/authoritarian political regimes. But for us authoritarianism is not a residue, nor a negative category primarily defined by those elements that are absent. It is instead a distinct category of political regimes. Democracy and authoritarianism thus become the two poles on a continuum of political alternatives. Notwithstanding the many insights realized by existing strands of the literature, we shall not try to delimit our contribution by joining in the common endeavour to label and count regimes quantitatively. Instead, we suggest qualitative distinctions between these two main regime types that are capable of grasping what is observed in country analyses, as well as phenomena perceived on trans-state and sub-state levels in the formation of 'polities.' ${ }^{\text {I4 }}$ At the same time, we look to base our approach on a strictly descriptive stance and to refrain from normative judgments such as 'progress' or 'improvement.' This does not mean, however, that we do not see certain trends and even commonalities within and across regime boundaries, as the section II of this article will elaborate in particular.

We believe that the political landscape of regimes, such as observable today, can be apprehended and explained by the different choices taken on the path of functional differentiation. Functional differentiation means that the closed social collectivities of pre-modern society, such as estate, caste and class, are pushed back by comparatively open communication systems, such as law, religion, education, the polity and the economy in modern society communication systems created around specific topics and complexes of meanings. Whereas in pre-modern society each individual person was a member of one and just one of these stratified social collectivities, and the individual's integration into a collectivity of this type defined and limited all the participations and activities available to this person, the modern situation is completely different. Every person is now partially involved in the operations of many (even potentially all) of the function systems of society. As one of these modern social systems, the polity holds ready the capacity to take collectively binding decisions (Luhmann, 2002). In this context, democratic and authoritarian regimes should be regarded as alternative options within the spectrum of political structures that enable collective decisions to be taken. As will be explained here and in the following section, in modern political systems the main distinctions characterizing regimes concern differences in the value patterns and inclusion formulas that inform this decision making.

\section{Contingent and Non-Contingent Values}

As the first variable underlying a distinction between democracy and autocracy, value patterns point to where and how values are respectively located and created in a society. ${ }^{15}$ Whereas in an authoritarian regime policy making is ori- 
ented towards external values of diverse societal origins ('heterogenesis'), democracies create values within the political process itself ('autopoiesis'). This implies that in the most fundamental understanding of what a democracy means, every possible issue can be subjected to an open-ended decision-making process on the input side. While for an autocracy values mostly function as premises and no doubts can arise regarding the validity and bindingness of these values, democracies function in a different way. Democratic political processes are observers of changes in societal values and, for them, it is a matter of continuous political deliberation if and how to translate value changes into legislative and political initiatives. Sometimes there are decisions and referenda that explicitly decree on values. In this respect, Switzerland might be regarded as a relatively pointed example of a political system in which national direct plebiscitary decision making (referenda) can even overrule internationally ratified human rights, as was probably the case with the 'minaret ban' incorporated into the Swiss constitution in 2009 following such a referendum. This decision may conflict with international human rights treaties signed and ratified by Switzerland and we do not yet know how the Federal Supreme Court of Switzerland (Bundesgericht, Tribunal Fédéral) in Lausanne would adjudicate were it asked to decide on a building permission for a future minaret.

What this example shows, moreover, is that there may be a kind of oscillatory movement observable in democratic political systems: in processes of endogenous value production, a political system can overstep its bounds and encroach on the terrain of another function system. In other cases, the self-limitation of democratic systems is a remarkable property that they often display: accepting the autonomy of other societal systems and even respecting their functional primacy on some issues - for example, involving the economy, law, the system of science or higher education. Then there is the other extreme: cases in which the openness of a democratic system to any value statement whatsoever is so strong that this liberality endangers its own survival - cases in which a democracy gives its adversaries such a free rein that it runs the risk of these enemies taking over and abolishing the same system to which they owe their existence and the possibility of articulation. ${ }^{16}$

At the authoritarian end of the spectrum, we characteristically encounter values that are external to the political system - i.e. they have not been created within it - and which steer the political process towards achieving a predetermined, or at least pre-envisioned, goal. Such non-contingent values often also entail a claim to be able to control 'the future' or the conditions under which decision making will have to happen at any given later moment - an aspect that is usually absent in political systems without exogenous values (Luhmann, 2002: I40-I69). These external values may be religious in kind or may be based on non-religious traditional/moral principles. As a further variant of values, one could think of forms of knowledge that are perceived as 
important and non-contingent in political processes and as indispensable for the political system's adaptability. Available knowledge then decides among political alternatives, resulting in expertocracy or technocracy as a regime type. Finally, regimes may be based on a specific sociopolitical ideology, crucially pre-structuring responses to societal problems, as in socialist/communist/fascist one-party-regimes, or perhaps in the ethno-nationalist regimes that may become more prominent in the near future (tendencies towards ethno-nationalism can be discerned even in seemingly well-established democracies such as India and Israel). In all these cases of authoritarianism, the political process is not a value or an end in itself and is not appreciated because of the openness of its outcomes, but it is, rather, a means towards a preordained goal.

Although values are different, at the level of the institutional structure and internal differentiation of the political system, modern authoritarian regimes often look quite like modern democratic regimes, featuring presidents, prime ministers, governors and mayors, governmental cabinets, parliaments, elections, parties, and associations. But these autocracies do not grant institutions and processes the ultimate autonomy to bring about just any imaginable result - a result that in a democracy will be accepted so long as it is produced by means of the representative and direct democratic processes institutionalized within the respective system. The possibility of endogenous self-negation and ultimately even self-destruction - a potentiality and sometimes a reality in democratic regimes - is not inherently probable under authoritarianism. What is also striking is that in authoritarian contexts the political system is often seen to claim authority and primacy (on the basis of non-contingent values) over other function systems, by rejecting the ultimate validity and autonomy of the law, or the complete self-organization of science or other foundations of autonomous knowledge. This is readily observed among populists, who typically refuse to consider the autonomous knowledge basis of other function systems. For them, there exist solely political statements that use the legitimacy of science and law as a veil. Populists seem to know the language of political power alone (power being the ultimate resource to either acquire or lose) and often fail to understand that other people speak the languages of other function systems and other value relevances.

\section{Authoritarian and Democratic Value Patterns in the Light of Functional Differentiation}

Functional differentiation is the most important, most constitutive feature of modern world society. Yet, as just mentioned, an authoritarian political regime regularly aims to establish a hierarchy of function systems in society in which the political system reserves for itself the capacity to enforce its non-contingent values over the values of other systems and, above all, can interfere in the operations of these other systems. This presumed legitimacy of intervention 
refers to even the most basic principles of inclusion in and exclusion from the other function systems.

Democracy, therefore, may plausibly appear as the modern embodiment of the political system in a functionally differentiated society as it recognizes no values external to itself and, in this way, claims and realizes functional autonomy. Only the ultimate valuation of individuality is non-contingent, even for democracies, and this includes the valuation of human rights that protect and contextualize modern individuality. Furthermore, democracy includes and accepts the political collectivities to which all individuals belong, and which are specifically modern collectivities. 'People' and 'nation' are the major terms for these modern political collectivities. Once again, though, these two terms indicate a commonality between modern democracies and autocracies as both regime types claim to be based on them. What distinguishes democracy and authoritarianism is that the latter system often inverts the primacy between individuals and the respective collectivities. Authoritarian systems claim to be based on the will of the people (as a collective unit often speaking with one voice) whereas democracies must go back to the articulation of interests by each individual member of a political system. As these articulations of interests will be diverse, pluralism is another value inherent to a democracy - a value that is a consequence of individuality and a valuation normally not shared with authoritarianism.

Beyond individuality (and the protective core of human rights around it) in a democracy only those values created by a polity's members within its constitutive democratic political processes are considered to matter and to be values internal to the polity itself. Only so long as a political system is able to respond to stimuli stemming from its social environment - finding solutions that seem adequate in content and claiming the amount of time necessary to find these solutions, solely via its own processes - can we consider it a democratic regime. It does not take much to imagine where and when alternatives could come into play. As soon as there is any value that functions as a precondition to the political process or is envisioned as the ultimate goal that cannot be altered during the political process, a tendency exists towards an authoritarian mode of politics.

This also explains why 'populism' should be considered an intermediary stage or a precursor to authoritarianism. Populism comes about as a shift from the self-organization of the decentralized and pluralistic democratic collectivity towards claims to offer more immediate representation of the "will of the people' made by a populist candidate and/or a populist movement. The latter claim to know the 'will of the people' and to be capable of immediately formulating this will. The populist usually comes from beyond the centre of the respective political system. $\mathrm{He} / \mathrm{sh}$ (for some reason, rarely a 'she') will often be an outsider and a newcomer unburdened by a history of compromises, pre- 
vious erroneous decisions or less successful earlier stints in public office. The immediate appeal to the 'will of the people' will have to be confirmed, at least once, by an often unexpected success in a political election, and thus still represents a democratic takeover of power by the populist/populist movement. But after this first success, populism will still claim its immediate and unmediated expression of the will of the people and will seek to avoid the possibility of being disconfirmed by later electoral defeats by a disappointed populace. There is a tendency, therefore, to rig future elections - and this indicates the path that leads from populism arising within a democracy to an authoritarian regime coming on its heels. This may be combined with the rise of values that become non-contingent - for example, efficiency and effectiveness in tackling economic downturns or rampant corruption, or values such as national sovereignty, territorial integrity and domestic stability and security, religious or ethnic purity - values that then explain the ongoing claim of the populist/ populist party to political domination and representation of the people.

Populism thus arises as a possibility when certain problems move to the centre of communicative attention and are perceived as so crucial that a) the time span usually needed to reach decisions through the established (selforganized) institutions of collective, fair and equal decision making appears to be too arduous and long, and b) the proposed solutions, or those that might be expected as outcomes of the usual policy-making process, are considered insufficient or inadequate. The offer of more immediate solutions based on other sources of authority (the populist party or strongman) and other types of expertise promising responsiveness to the perceived problems may then become attractive. This includes the fact that in the process of building an authoritarian regime, the decentralized, pluralistic, diversity-seeking search structures characteristic of a democracy become more or less completely dismantled (Stichweh, 20I6b: 24-27).

\section{THE CAREER OF INDIVIDUAL POLITICAL INCLUSION: THE DIFFERENT CON- STITUTION OF POLITICAL ROLES IN DEMOCRATIC AND AUTHORITARIAN POLITICAL SYSTEMS}

We have pointed to formulas of political inclusion as another core element of our approach to capturing regime bifurcations. This will require some further explanation.

The global emergence of democratic regime types is usually seen as equivalent to the emergence of a historically new order of inclusion in politics. As the equal inclusion of all individuals is the internally created, underlying principle for democratic political regimes, democracies appear as the almost ideal embodiment of modernity in politics. But does this coupling of democracy and universal political inclusion provide an argumentative basis for expectations concerning the ultimate advance of democracy, as has been postulated in the more teleologically inclined research on democratization? Alter- 
natively: how can we make sense of the resilience of alternatives to democracy? We argue that, as such, the imperative of individual inclusion must be regarded as the most fundamental innovation - representative of modernity - that is the undertone of all political development in world society. While we would agree with the claim that a democratic regime, in theory, represents the full implementation of this idea, the career of individual inclusion is observable even across regime types. To trace this career, we suggest refining once again our definition of political inclusion, since it appears that both popular and scientific discourses lack a nonbiased perspective on - and a concept of - 'political inclusion' that is not immediately used interchangeably with 'democracy.' Without evaluating their legitimacy or meaningfulness, it is first of all interesting and necessary to observe that there are not only differences in what we call inclusion formulas between different regime types, but also among regional variants of the 'same' regime type. ${ }^{\text {I7 }}$

\section{Political Individuality and Political Inclusion Roles}

As is true for all the function systems of world society, the political system defines its own concept of individuality, and does so in a way specific to the function system, thereby producing semantics and variants of political individuality that form the starting point for defining inclusion roles in different political regimes. Two major aspects of political individuality can be meaningfully distinguished. Once more we are dealing with a bipolar structure that separates a mental pole from an action pole of political individuality. ${ }^{18}$ On the mental (experiential) side, the political individual is primarily seen as an observer who contributes interests and opinions to political processes. On the opposite side, which can meaningfully be described as the action aspect of political individuality, an individual is primarily an actor (endowed with agency) contributing action and active engagements to the ongoing events constitutive of the political process. The early modern distinction of interests and virtue somehow reconstructs (and, of course, anticipates) this bipolarity of political individuality (see Pocock, I975).

This bipolarity of political individuality is matched by the two alternative and complementary versions of political inclusion roles. In each function system of society we find public roles (which may also just be observer roles if there is a certain prevalence of passivity) and performance roles (roles for producers of system defining activities) (see Stichweh, 20I6a). In some cases, only the public role is accessible to most of the individuals included in the respective function system. The health system is a good example: everybody will become a patient (meaning someone who has to be patient in suffering) at some point in his or her life, while most persons will never be a doctor (working to remedy the patient's problems). This is clearly an asymmetrical role structure: there are those who do people-processing and those who are processed. Modern politics, especially in its democratic version, is quite dif- 
ferent. The concept of democratic political individuality seems to demand the potentiality of inclusion in both types of political inclusion roles. Everybody is an observer of the ongoing events in their own system (and of all the other systems worldwide) and can therefore opt for the elementary possibilities available to participation through public roles (interest-based voting, communication of opinions, participation in protests). Yet, at the same time, everybody is able and legitimized to switch over to the other side of the disjunction in political roles and emerge as an actively engaged and virtuous political actor to whom, in principle, any performance role is accessible. Everybody, without exception, can become the 'President' of the United States or the 'Chancellor' of the Federal Republic of Germany - and recent history has demonstrated that this is not a virtuality but a reality in both countries. This non-exclusionary universal inclusion into both role types of the political system seems to result from modern political individuality and to be a non-negotiable aspect of democratic political systems. But there are interesting alternatives to be observed, which, as alternatives, define different political regimes.

Firstly, there is the possibility - and the historical reality - of a political system in which the public role of an observer with privatized interests is not provided for (and perhaps not seen as legitimate). In such systems, everybody involved in politics must assume a performance role, that is, participate as an active citizen endowed with public virtue (which pushes back private interests). From an ideological point of view, this kind of system is definable as republicanism and, in structural and historical terms, its realization is only conceivable as an aristocracy formed by a significant number of bearers of performance roles whose interrelations are defined by equality towards one another. The number of active role bearers in such an aristocratic republic is not necessarily small, but it is clearly limited quantitatively. The inclusion of everyone is neither intended nor indeed permitted. An aristocratic elite is, by definition, always a minority in the political system, which it governs in aristocratic fashion. Aristocracies were a very prominent type of political regime in early modern Europe (sixteenth to eighteenth century), ${ }^{\text {ig }}$ but they seem to have disappeared from the present-day world. This suggests that aristocracies are probably incompatible with the inclusion imperative of modernity.

\section{The Possibility of Modern Inclusive Authoritarianism}

Two alternatives remain. First, there is a political system that realizes universal inclusion in public and performance roles. This is democracy, and again there are many variants. In some democracies the switch from a public to a performance role is a distant possibility, one rarely realized at a later point in a citizen's life. In other democratic systems - perhaps Switzerland is the best example - all performance roles are designed in such a way that the universality of inclusion in performance roles is maximized. ${ }^{20}$ 
Finally, coming back to the major distinction explored in this paper, we have autocracies or authoritarian regimes, which do not admit universal inclusion in performance roles. This would represent a risk they cannot afford to take. Performance roles are reserved to a small segment of the population, considered to consist of the guardians of the value principles on which the authoritarian regime is based. This may be a party, a kind of clerisy (religious or otherwise ideologically unified) or any other social structure apt to assume this role of guardianship. But authoritarian systems are also modern in allowing and being based on universal inclusion of everyone in public roles. They claim to act in the interest of everyone, the paths for exercising influence (elections, petitions, protests) are open to everyone, except to members of stigmatized and thus excluded populations that conflict with the value principles of the authoritarian regime. Regarding the processes of mutual influence between performance roles and public roles, authoritarian regimes once again tend to invert the direction of flows of influence. They often conduct mass mobilizations from the top of the political system and, in this way, replace the possibilities for each single individual to participate in the system with strat egies designed to control the population via mass mobilization. This switch from individualized participation (beginning with individual role bearers) to processes of mass mobilization - trying to include each and every individual - is one of the reasons why autocracies prefer the modern collectivities (i.e. nation, people) to which the many individuals are supposed to belong, in contradistinction to the potential for influence resting on individual role bearers. Of course, mass mobilization does differ between different authoritarian regimes. Only in the case of totalitarian types of authoritarianism (such as fascism or Stalinism) is mass mobilization actually based on the compulsory inclusion of everyone. Modern authoritarianisms do not need everyone. They can withstand a certain amount of indifference and also pluralism. Moreover, they can shift their mode of legitimation from the mobilisation and participation of the whole populace to inclusion in the outputs of political processes. In other words, while access to performance roles remains largely restricted, in the case of modern authoritarianism, more equal inclusion into public roles (recipients of welfare benefits and the like) can be observed, which again denotes the inclusion imperative germane to modern society. Finally, as mentioned earlier, modern autocracies attempt to legitimate themselves by claiming the superiority and effectiveness of the authoritarian regime compared to 'messy' and ineffective democracies. If and when effectiveness tangibly fails, they may revert to mass mobilization, which may well prove to be their demise. ${ }^{21}$ 


\section{FORMS OF INTERNAL DIFFERENTIATION OF DEMOCRACIES AND AUTOCRACIES: VERTICAL LEVELS AND HORIZONTAL SUBSYSTEMS}

Up to this point, this paper, in comparing democracies and autocracies in the contemporary world, has analysed the production, change and invariability of the value patterns characteristic of democracies and autocracies, along with the modern inclusion imperative, which is found as an operative principle in all the function systems of world society. An analytical interest in forms of political inclusion turns out to be a good instrument to capture the modernity even of autocracies in a world which has often been described by the revolution in democratic inclusion beginning in the eighteenth century. A third form of comparison of the two regime types, with which we shall conclude this article, pertains to another core aspect of political modernity: the enormous complexity of modern political systems, as shown in their multiple forms of internal differentiation. Once more our question is: in what ways does the bipolarity of democracy and authoritarianism become visible when we examine this core dimension, the ongoing internal differentiation of contemporary political systems?

\section{A. Multilevel Structure of Contemporary Political Systems}

The contemporary system of approximately 200 nation states is still the dominant level for the identification and analysis of political regime types in today's world society. Growing transnational cooperation and global governance do not significantly challenge this observation. Why is this so? One possible argument is that decision making that is binding for an identifiable collectivity of individuals still primarily occurs within the scope of a single country's jurisdiction, combined with the fact that citizenship - and with it the rights essential to meaningful political participation and to political outputs - are still tied to the nation state. Nonetheless, even if we focus on the nation state, a multitude of levels of decision making can be identified within any nation state and, at all these levels, the semantics and roles of political inclusion arise and diversify political systems.

It is common to integrate various subnational and supranational perspectives into research on democratic politics. This is reflected, for instance, in the old and extensive debate on size and democracy. In the early i97os, Robert A. Dahl and Edward R. Tufte, among others, took up the strands found in traditional political philosophy to ask: "how large should a political system be in order to facilitate rational control by its citizens?" (Dahl \& Tufte, I973: I) and "what is the appropriate political unit for expressing one's identity as a member of a community" (Dahl \& Tufte, I973:3) during an era of increasing complexity and diversity in an urbanizing and globalizing world? Today, more than forty years after their seminal publication, these questions still remain pertinent and, as mentioned above, translate into research on community participation and local self-administration, the appropriate design of constituencies, representation in and control of transnational and international unions, and many other aspects (see, for example, Denters et al., 20I4). 
Empirical comparative research on authoritarianism, however, does not usually explore questions concerning the complexity of the modern polity. Analyses are mostly anchored at the level of the nation state and the top echelons of political power structures. ${ }^{22}$ This is rather surprising, since it is a prominent feature of autocracies that they distinguish between different tiers of the political system, which are then related to different principles and degrees of inclusion in collectively binding decision making. For instance, while the national political leadership is unchallenged and inaccessible, and its decisions determinate, modern variants of output-oriented 'adaptive authoritarianism' often heavily rely on local (sometimes experimental) adjustments of policies, including different forms of participation by the 'affected' parts of the population. It could, therefore, easily be assumed that the more local the perspective, the more opportunities for individual participation would arise - i.e. the more inclusive politics should become, even in autocracies. This has been, for instance, vividly described for the People's Republic of China (see, for example, Ahlers, 20I4; He \& Thøgersen, 20I0; Schubert \& Ahlers, 20I 2) and Russia (see Moser, 20I5, forthcoming). More research that goes beyond the national level ${ }^{23}$ in the study of autocracies and authoritarianism is needed to test this hypothesis.

Exemplary levels of the polity with relevance for collectively binding decision making, and related categories and organizations of inclusion 
Without claiming to present a complete list, we suggest that a study of the different levels of a polity should be open to accommodate any institutional configuration in which collectively binding decision making occurs: for example, at grassroots/community, regional, trans-regional and trans-boundary, national, international and global levels. Important questions to be asked in each case should include:

- What is decided upon and why (based on contingent or non-contingent value patterns)?

- Who is included in the decision-making process, on what basis, and in what way, i.e. in a public role or a performance role? (e.g. form of representation; direct or indirect election into performance roles, etc.).

- How, and with what effect are decisions taken? (e.g. majority overrules minorities; experts overrule 'non-knowledgeable' voters/majorities; collective integrity overrules individual integrity, or vice versa; law overrules elections/referenda/majorities/protests, or vice versa).

From a general perspective, a core question will certainly be: how do autocracies deal with the control/effectiveness bipolarity built into the differentiation of decision-making levels? Having multiple levels of decision making always entails a potential loss of control for higher levels, a fact usually welcome in democracies (think of the 'subsidiarity principle') but which may be problematic in autocracies. On the other hand, a plurality of levels seems to promise a higher degree of effectiveness in terms of realizing policies, based on the capacity for more adequate local adjustments: something with appeal for autocracies insofar as they try to win legitimacy by claiming to be more effective than democracies.

\section{B. Horizontal Differentiation of Subsystems and the Plurality of Access Points for Inclusion}

Looking at the vertical differentiation of levels helps us transgress the limitation of analysis to the nation state level in research on political regimes, but it still rests on an understanding of inclusion as access to and representation in formal - and one might say, conventional - institutions of ultimate decision making, usually the 'legislative' and the 'executive.' But there are more - and more complex - structures within any given political system that need to be considered. In close connection with this openness to the existence of multilevel variation, we also need to identify and describe relevant political subsystems and other elements of horizontal differentiation.

In the classical understanding of horizontal differentiation of the political system, we distinguish political subsystems, which comprise party politics, government and public administration, from the public sphere ('Öffentlichkeit') (cf. Luhmann, 2002). Aside from these classical cases, there is also the military as a partially autonomous organization, and social movements as 
the relatively recent emergence of a new social form. In authoritarian systems, membership in parties and mass organizations is often very important.

Below, we briefly discuss some examples that, in our view, can serve as a fruitful basis for future empirical research on the bipolarity of authoritarianism and democracy:

The possibility and characteristics of inclusion via party membership and mass organizations. It must be examined whether in historical and contemporary one-party regimes, party membership is really obligatory (for performance roles), and how important and effective it is for political inclusion. Interestingly enough, in communist/socialist regimes, party membership does foster elitist as well as inclusive structures. The Communist Party of China, for instance, has shown how membership can be ideologically - and indeed functionally modified, since it now also welcomes private entrepreneurs and claims to represent them (see, for example, Dickson, 2008). ${ }^{24}$ Authoritarian regimes usually also seek to penetrate society via other mass organizations with compulsory membership, including youth leagues and trade unions. On the opposite side, democracies seem not to rely to the same degree on (freely chosen) membership in political parties, since, besides the complex processes internal to parties and the party system, there exist further milieus (publics) relevant to political agenda setting and decision making. In democratic systems, privileges for party members in some ways conflict with the universality of inclusion in the possibilities for participation and, therefore, they often try not to institutionalize such privileges to such a degree that it becomes a principle of exclusion (consider, for example, the organization of primaries in the United States).

Inclusion into administration via extended client and secondary performance roles. ${ }^{25}$ In modern societies, it seems that access to performance roles in administration, as well as interaction with these roles from the perspective of public roles, is increasing, while at the same time the differentiation and asymmetry of these two role types is becoming less pronounced. This applies to the general structures of administrative communication (the former 'subjects' of public administration become 'clients') and also to participation in specific processes - via deliberative practices, for instance (see, for instance, Dryzek, 2006). Interestingly enough, this seems to be a dynamic largely independent of the political context, i.e. the regime type, and also a trend detectable around the globe, as self-descriptions and the repertoire of modern administration become similar (see Pollitt \& Bouckaert, 2004; Treutner, I994).

Inclusion via trans-regional and trans-national networks and organizations. In some cases, there may exist trans-regional and trans-national networks and organizations that have distinct relevance for collectively binding decision making and for the distribution of public goods, yet are in conflict with other institutions established within the political system. These may take, for instance, 
the form of a 'parallel/grey state,' as has been claimed regarding the Muslim brotherhood (see Roy, 20I3). We might also include Catholic organizations like 'Opus Dei' or the Jesuit Order as other prominent examples.

Inclusion via social movements. Social movements can encompass participatory publics or outright protest through formal channels (e.g. debate, petitioning) or informal, even illegal, means (violent protest, riots, occupation). Again, the potential for inclusion in the form of extra-parliamentary and sometimes even extra-legal claims or correctives would seem to be a paradigmatic context for studying traits of democratic or authoritarian politics.

The further virtualization of inclusion through the increasing and increasingly autonomous relevance of 'public opinion.' The virtualization of inclusion, as well, is a tendency observable largely independent of regime type. Traditionally relevant for the anticipation of election results in democratic contexts, traditional and new (social) media debates and other representations of a diverse population, 'public opinion' has also found its place in authoritarian politics as a means of information gathering, a feedback mechanism, and for indirect agenda setting. This is especially true for regimes that live in constant fear of stability-eroding opposition and are thus interested in acting at least partially in response to public demands (see Wang, 2008). The extreme prominence of public surveys, for instance, in US and - albeit to a lesser degree European politics, as well as the massive - and recently much more than ever outward-oriented - efforts to politically control public debate and the media in authoritarian contexts (in particular, in China, Singapore, Russia, Egypt and Saudi Arabia, for example) seem to be interesting starting points for research in this area (see Diamond, Plattner \& Walker, 2016).

\section{CONCLUSION}

Classifying political regimes remains a crucial, yet quite complex endeavour in world society. We have suggested that the main distinction between regimes in the political space today can be found in the two poles of democracy and authoritarianism. Furthermore, in tandem with the seeming 'return of authoritarianism,' or at least the resistance to and reinforcement of authoritarian claims to rule, a topic often neglected is the global career of political inclusion.

We therefore critically revisited the analytical distinctions political between regimes and proposed an alternative that allows for extensive investigations both inside and beyond the boundaries of the nation state unit. After introducing an approach to political regime bipolarity that rests on value patterns in modern political systems, we have suggested a closer analysis through tracing different forms of political inclusion and its evolution in both democracies and autocracies. At the same time, we have argued that both democratic and authoritarian traits can co-exist in one and the same political system. 
The article did not provide causal explanations for why particular types of autocratic regimes have come into being and persist. Also, we do not attempt to advance authoritarian forms of political inclusion as full-fledged alternatives to democracy. We do claim, however, that their critical comparative assessment can contribute to a more complete understanding of modern polities and politics and their dynamics. Altogether, we tend to see paradoxes and oscillations between two poles of a political space in today's world society. The clearest divisions seem to exist between political inclusion based on individuality versus political inclusion either conditioned by social categories or understood collectively - an observation that has yet to be corroborated by further studies. This dimension is complemented by the distinction of universal inclusion into public roles and selective or universal inclusion into performance roles, which again correlates with the distinction between democracy and authoritarianism.

While our proposals regarding the distinction between democracy and authoritarianism probably appear simplified compared to the taxonomies proposed by the usual regime research literature, our suggestions for empirical analyses propose complexity not simplicity. They demand a thorough understanding of the political system, its (historical) semantics of belongingness and citizenship as a semantics of inclusion, its institutionalized value patterns, and finally the different levels of the polity and political subsystems. We believe that these explorations represent a fruitful undertaking, not only in terms of encouraging insightful empirical analyses, but also for furthering the theoretical acuity of research on political system bifurcation and political evolution in world society.

Received I6/9/2019 | Approved 20/10/2019

Anna L. Ahlers is a professor in the Department of Culture Studies and Oriental Languages at University of Oslo. She published, among others, Rural Policy Implementation in Contemporary China. New Socialist Countryside (20I4).

Rudolf Stichweh is Dahrendorf professor for "Theory of Modern Society" at the University of Bonn, and director of the associated Forum Internationale Wissenschaft. His publications include: Inklusion und Exklusion [Inclusion and Exclusion] (2. rev. ed. 20I5) and Der Fremde [The Stranger] (20I0). 


\section{NOTES}

I See, for example, discussions in Diamond (20II), Markoff (20I5), Lehoucq (20I0).

2 Also see Diamond (20I5). However, some debate exists regarding the validity of this observation, based as it is on different indicators and numbers; see, for instance, Levitsky and Way (2015). For a review of the latest, more philosophical literature on the "trap, tragedy or crisis" of democracy, see Hobson (2016).

3 We find extreme differences between the continuing selfdescription of the regime, by CCP ideologues, as "socialism with Chinese characteristics" and the various contrasting labels employed by external observers.

4 See, for example, Pei Minxin (2006); Gat (2007). Also see Bueno de Mesquita et al. (2005); Shen (2007); Wintrobe (I998).

5 See too the countless publications on the 'China Model' - for example, the critical account contained in the special issue "Debating the China Model of Modernization" of the Journal of Contemporary China (He \& Thøgersen, 20I0). Or the recent reemergence of the debate on the 'Singapore model' following Lee Kuan-Yew's death in March 2015 (Caryl, 20I5).

6 See, for example, Beeson (2010).

7 See the comprehensive review of the state of the field in Albrecht and Frankenberger (20I0).

8 The notion of evolution, as used here, implies no teleology and no set trajectory, but rather a constant adaptation. See also the long tradition in political science of discussing and applying evolution "seriously or metaphorically," reviewed in $\mathrm{Ma}$ (2014).

9 See the contributions in the Journal of European Integration (2013).

Io See the collection of articles in West European Politics (2002).

I I Illuminating examples can be found in Sejersted (20II).

I 2 Function systems are global communication systems built around specific types of social problems that are not dealt with in other systems (Stichweh, 2013). 
I3 See, for instance, the summarizing matrix in Møller and Skaaning (2013), in which the indicators competitive elections, inclusive elections with high integrity, civil liberties, and rule of law determine a ranking of democracies, as well as the separation of democracies from non-democracies.

I4 Our approach to the bipolarity of democratic and authoritarian regimes is part of an ongoing research program at the 'Forum Internationale Wissenschaft,' University of Bonn, available at: <https://www.fiw.uni-bonn.de/demokratieforschung/abteilung-demokratieforschung>. More detailed analyses will be presented in a forthcoming book (Ahlers et al., 2020).

I5 We define values with Kluckhohn and Parsons as "conceptions of the desirable type of society" (Parsons \& Shils, I95I).

I6 This danger is most often discussed in connection with democracy being in principle open to the rise of demagoguery and populism, as will be taken up again below. The fact that democracy is the "rule of the majority" and related worries about the danger of a highly exclusive "tyranny of the majority" have troubled ancient philosophers, early political analysts (such as Tocqueville) and contemporary historians alike; see, for instance, Lukacs (2005); Mudde and Kaltwasser (20I2).

I7 It may even be argued that in the political system, inclusion formulas are a bit more complex to grasp and categorize than in other social systems. However, systems always tend to claim that they are more complex, more multi-stranded, than other systems (Fox, I978).

I8 In terms of sociological systems theory, this corresponds to the distinction between Erleben and Handeln (experience and action); see Luhmann (I98I).

I9 For Poland-Lithuania as a prominent example, see Davies (2005).

20 Switzerland calls this the 'Milizprinzip.' Since a militia is a type of military organization in which every citizen can take an active role, the Milizprinzip implies the generalization of this pattern to other societal sectors. The Milizprinzip also entails that there are only part-time performance roles. There are no - or nearly no - full-time 
political professionals. The Swiss 'Nationalrat' with its part-time parliamentarians is a good example.

2I The last two days of the Ceausescu regime (December 2I22, I989) are a good example; see Sebestyen (2009, Ch. 48).

22 Most often it is institutional change at this level that captures the attention of comparative studies of political regimes. For what are regarded as modern types of authoritarian regimes or political subsystems, for example, it is acknowledged that rulers have been able to establish structures of rule that outlived their founders and that led to institutionalized forms of leadership transition, as documented in cases such as China, Saudi Arabia, Russia, Iran and some countries in South Asia and Sub-Saharan Africa.

23 Moreover, this may even go both ways, sub-national and supra-national, as there is an emerging body of research pointing towards an "international cooperation of authoritarian regimes"; see, for example, Erdmann et al. (2013).

24 For a more general view, see especially Heberer's (20I6) recent and very thorough reflections on the concept of representation and its application to and within China.

25 Secondary performance roles are performance roles temporarily or partially assumed by lay people/amateurs or non-professionals. They can also be defined as activist alternatives to pure public roles; see Stichweh (20I6a, Ch. I).

\section{BIBLIOGRAPHY}

Ahlers, Anna L. (20I4). Rural policy implementation in contemporary China: new socialist countryside. London: Routledge.

Ahlers, Anna L. et al. (2020). Sociology of contemporary political systems: differentiation and inclusion. Bielefeld: Transcript.

Al Jazeera (n.a.). (20I5). Saudi Arabia Elects Its First Female Politicians. Available at <http://www.aljazeera.com/ news/20I5/I2/women-win-seats-landmark-saudi-arabia-elections-I5I2I3054750832.html> Accessed 24 Feb. 2016.

Albrecht, Holger \& Frankenberger, Rolf. (2010). Autoritarismus Reloaded: Konzeptionelle Anmerkungen zur Vergleichenden Analyse politischer Systeme. In: Albrecht, 
Holger \& Frankenberger, Rolf (eds.). Autoritarismus Reloaded. Neuere Ansätze und Erkenntnisse der Autokratieforschung. Baden-Baden: Nomos, p. 37-60.

Beeson, Mark. (2010). The Coming of Authoritarian Environmentalism. Environmental Politics I9/2, p. 276-294.

Birke, Sarah. (2015). How ISIS Rules. The New York Review of Books, 62/2.

Bueno de Mesquita, Bruce et al. (2005). The logic of political survival. Cambridge: The MIT Press.

Caryl, Christian. (20I5). Africa's Singapore Dream. Why Rwanda's president styles himself as the heir to Lee Kwan Yew. Foreign Policy. Available at <http://foreignpolicy. com/20I5/04/O2/africas-singapore-dream-rwanda-kagame-lee-kuan-yew/>. Accessed 2 Apr. 2015.

Dahl, Robert Alan \& Tufte, Edward R. (1973). Size and democracy. Stanford: Stanford University Press.

Davies, Norman. (2005). God's playground. A history of Poland. The origins to I795. New York: Columbia University Press, rev. ed.

Denters, Bas et al. (2014). Size and local democracy. Cheltenham: Edward Elgar Publishing.

Diamond, Larry J. (2015). Facing up to the democratic recession. Journal of Democracy, 26/I, p. I4I-I55.

Diamond, Larry J. (20II). A fourth wave or false start: democracy after the Arab Spring. Foreign Affairs, 22. Available at <https://www.foreignaffairs.com/articles/middleeast/20II-05-22/fourth-wave-or-false-start>. Accessed 3 Jan. 2016.

Diamond, Larry J. (2002). Thinking about hybrid regimes. Journal of Democracy, I3/2, p. 2I-35.

Diamond, Larry; Plattner, Marc F. \& Walker, Christopher. (2016). Authoritarianism goes global: the challenge to democracy. Baltimore: A Journal of Democracy Book.

Dickson, Bruce. (2008). Wealth into power. The Communist Party's embrace of China's private sector. Cambridge: Cambridge University Press.

Dryzek, John. (2006). Deliberative Democracy in Different Places. In: He, Baogang \& Leib, Ethan J. (eds.). The search for deliberative democracy in China. New York: Palgrave Macmillan, p. 23-36. 
Economist Intelligence Unit. (20I4). The EIU Democracy Index for the Year 20I4. Available at <https://www.eiu.com/ public/topical_report.aspx?campaignid=DemocracyoI I5 $>$. Accessed 3 Jan. 2016.

Erdmann, Gero et al. (2013). International Cooperation of Authoritarian Regimes: toward a conceptual framework. Giga Working Papers, 229. Available at <https://www.gigahamburg.de/en/publication/international-cooperation-ofauthoritarian-regimes-toward-a-conceptual-framework>. Accessed Io Feb. 2015.

Fox, Renée C. (1978). Why Belgium? European Journal of Sociology, I9/2, p. 205-228.

Gat, Azar. (2007). The return of authoritarian great powers. Foreign Affairs, 48/4, p. 59-69.

Giraudy, Agustina. (20I5). Democrats and autocrats. Pathways of subnational undemocratic regime continuity within democratic countries. New York: Oxford University Press.

He, Baogang \& Thøgersen, Stig. (20I0). Giving the people a voice? Experiments with consultative authoritarian institutions in China. Journal of Contemporary China, I9/66, p. 675-692.

Heberer, Thomas. (2016). Reflections on the concept of representation and its application to China. Working Papers on East Asian Studies, I Io.

Hertog, Steffen. (20II). Princes, brokers, and bureaucrats: oil and the State in Saudi Arabia. Ithaca: Cornell University Press, reprint.

Hobson, Christopher. (2016). Democracy: trap, tragedy or crisis? Political Studies Review. Online first, doi: IO.II77/478929916663756.

Journal of European Integration. (2013). Does one come at the expense of the other? Special Issue, 35/5-Representation and Democracy in the EU.

Lehoucq, Fabrice. (2010). The third and fourth waves of democracy. In: Haynes, Jeffrey (ed.). Routledge handbook of democratization. London: Routledge, p. 273-286.

Levitsky, Steven \& Way, Lucan. (20I5). The myth of democratic recession. Journal of Democracy, 26/I, p. 45-58. 
Levitsky, Steven \& Way, Lucan. (2010). Competitive authoritarianism: hybrid regimes after the Cold War. Cambridge: Cambridge University Press.

Levitsky, Steven \& Ziblatt, Daniel. (20I8). How democracies die. New York: Broadway Books.

Luhmann, Niklas. (2002). Die Politik der Gesellschaft. Frankfurt: Suhrkamp.

Luhmann, Niklas. (198I). Erleben und Handeln. In: Niklas Luhmann. Soziologische Aufklärung 3. Opladen: Westdeutscher Verlag, p. 67-80.

Lukacs, John. (2005). Democracy and populism: fear \& hatred. New Haven: Yale University Press.

Ma, Shu-Yun. (2014). Taking evolution seriously, or metaphorically? A review of interactions between historical institutionalism and darwinian evolutionary theory. Political Studies Review, I4/2, p. 223-234.

Markoff, John. (2015). Waves of democracy: social movements and political change. Boulder: Taylor \& Francis Ltd, 2. rev. ed.

Merkel, Wolfgang. (2004). Embedded and defective democracies. Democratization, II/5, p. 33-58.

Mickey, Robert. (20I5). Paths out of Dixie. The democratization of authoritarian enclaves in America's Deep South, 19441972. Princeton: Princeton University Press.

Møller, Jorgen \& Skaaning, Svend-Erik. (2013). Regime types and democratic sequencing. Journal of Democracy, 24/I, p. I42-I55.

Moser, Evelyn. (2015). Postsowjetische Transformationen in der Weltgesellschaft: Politische Dezentralisierung und wirts chaftliche Differenzierung im ländlichen Russland. Bielefeld: Transcript.

Moser, Evelyn. Forthcoming. The logic of the Soviet organisational society. Political control, the Soviet village, and world society. In: Hayoz, Nicolas \& Stichweh, Rudolf (eds.). Soziale Systeme - Sonderband. Variants of differentiation in the regions of world society.

Mudde, Cas \& Kaltwasser, Cristóbal Rovira (eds). (2012). Populism in Europe and the Americas: threat or corrective for democracy? Cambridge: Cambridge University Press. 
Parsons, Talcott \& Shils, Edward (eds.). (I95I). Toward a general theory of action. Cambridge, Mass.: Harvard University Press.

Pei, Minxin. (2006). China's trapped transition. The limits of developmental autocracy. Cambridge: Harvard University Press.

Pocock, John G. A. (1975). The machiavellian moment. Florentine political thought and the Atlantic Republican tradition. Princeton: Princeton University Press.

Pollitt, Christopher \& Bouckaert, Geert. (2004). Public management reform: a comparative analysis - new public management, governance, and the neo-weberian State. Oxford: Oxford University Press, 2 ed.

Ramo, Joshua Cooper. (2004). The Beijing consensus. The Foreign Policy Center. Available at <http://fpc.org.uk/ fsblob/244.pdf $>$. Accessed Io Jul. 2016.

Roberts, Alasdair. (20I2). Why the Occupy Movement failed. Public Administration Review, 72/5, p. 754-762.

Roy, Olivier. (2013). There will be no Islamist revolution. Journal of Democracy, 24/I, p. I4-I9.

Runciman, David. (2018). How democracy ends. London: Profile Books.

Schedler, Andreas (ed.). (2006). Electoral authoritarianism. The dynamics of unfree competition. Boulder/London: Lynne Rienner.

Schubert, Gunter \& Ahlers, Anna L. (2012). Participation and empowerment at the Grassroots: Chinese village elections in perspective. Lanham: Rowman \& Littlefield.

Sebestyen, Victor. (2009). Revolution I989. The fall of the Soviet Empire. London: Weidenfeld and Nicolson.

Sejersted, Francis. (20II). The age of social democracy: Norway and Sweden in the twentieth century. Princeton: Princeton University Press.

Shen, Ling. (2007). When will a dictator be good? Economic Theory, 3i/2, p. 343-366.

Stichweh, Rudolf. (2016a). Inklusion und Exklusion. Studien zur Gesellschaftstheorie. Bielefeld: Transcript. 
Stichweh, Rudolf. (20I6b). Politische Demokratie und die funktionale Differenzierung der Gesellschaft. FIW Working Paper Series, 3. Bonn. Available at <https://www.fiw. uni-bonn.de/publikationen/FIWWorkingPaper>. Accessed Io Aug. 2016.

Stichweh, Rudolf. (2013). The history and systematics of functional differentiation in sociology. In: Albert, Mathias et al. (eds.). Bringing sociology to international relations. World politics as differentiation theory. Cambridge: Cambridge University Press, p. 50-70.

Treutner, Erhard. (I994). Verwaltung und Publikum. In: Dammann, Klaus; Grunow, Dieter \& Japp, Klaus P. (eds.). Die Verwaltung des politischen Systems. Neuere systemtheoretische Zugriffe auf ein altes Thema. Opladen: Westdeutscher Verlag, p. 215-227.

Wang, Shaoguang. (2008). Changing models of China's policy agenda setting. Modern China, 34/I, p. 56-87.

West European Politics. (2002). Non-Majoritarian Institutions in Europe. Special Issue, 25/I - The Politics of Delegation.

Wintrobe, Ronald. (I998). The political economy of dictatorship. Cambridge: Cambridge University Press.

Zakaria, Fareed. (I997). The rise of illiberal democracy. Foreign Affairs, 76/6, p. 22-43. 
A BIPOLARIDADE DE DEMOCRACIA E AUTORITARIS-

846 MO: PADRÕES VALORATIVOS, INCLUSÕES DE PAPEIS

E FORMAS DE DIFERENCIAÇÃO INTERNA DOS SISTE-

MAS POLÍTICOS

Resumo

O artigo começa com a observação de que a sociedade mundial de hoje exibe uma bipolaridade em seu regime político e sugere uma interpretação baseada nas teorias sociológicas da inclusão e diferenciação funcional. Assim, (I) distinguimos os regimes políticos entre democráticos e autoritários, identificando os padrões valorativos subjacentes às decisões coletivamente vinculantes em cada caso. A democracia é entendida como um regime político baseado na 'autopoiese' de seus valores constitutivos, ao passo que em regimes autoritários observamos uma 'heterogênese' de seus valores. Com isso, acrescentamos (2) a ideia de que os estados modernos são caracterizados pelo imperativo da inclusão política individual; ao mesmo tempo, novos padrões surgem para a inclusão de coletividades. Concluindo, (3) postulamos que essa abordagem permite o estudo das transformações em curso nos processos de diferenciação nos dois tipos de regimes, fechando o argumento com a apresentação de uma visão geral da hierarquia de níveis nos processos políticos modernos e a diferenciação horizontal de subsistemas e organizações.

\section{THE BIPOLARITY OF DEMOCRACY AND} AUTHORITARIANISM: VALUE PATTERNS, INCLUSION ROLES AND FORMS OF INTERNAL DIFFERENTIATION OF POLITICAL SYSTEMS different value patterns underlying collectively binding decision making. Democracy is understood as a political regime based on the 'autopoiesis' of its constitutive values, while in authoritarian regimes we observe a 'heterogenesis' of values. To this we (2) add the idea that modern states are characterized by the imperative of individual political inclusion. At the same time new patterns arise for the inclusion of collectivities. Concluding (3), we postulate that this approach allows the study of ongoing transformations of differentiation in both types of regimes. In this part, we present an overview of the hierarchy of levels of modern polities and the horizontal differentiation of subsystems and organizations.
Palavras-chave

Democracia; autoritarismo; inclusão; valores sociais; diferenciação interna.
Keywords

Democracy; authoritarianism; inclusion; societal values; internal differentiation. 